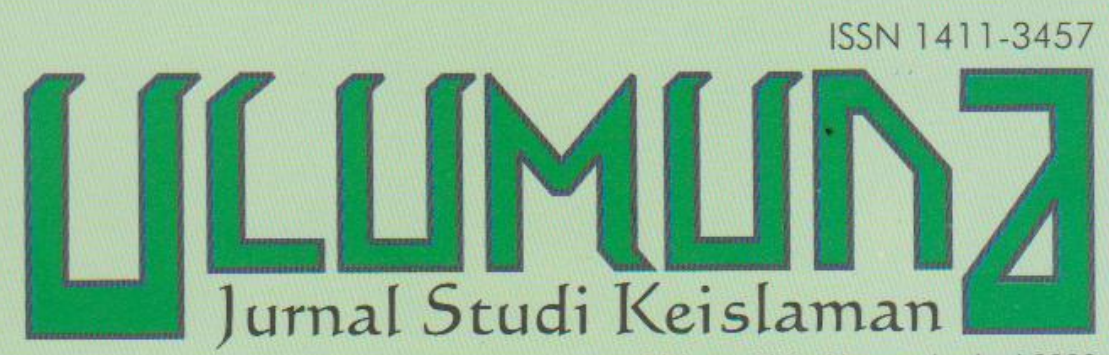

Volume XIII• Nomor $1 \cdot$ Juni 2009

TERAKREDITASI Berdasarkan SK Dirjen Dikti Depdiknas Nomor: 65a/DIKTV/Kep/2008

PEMIKIRAN FIQH DAN SPIRIT TRANSFORMASI SOSIAL Miftahul Huda

PERSPEKTIF MUHAMMAD SAT́D AL-ASYMÂWI TENTANG HISTORISITAS SYARI'AH Mutawalli

ASAS RETROAKTIF PADA KASUS PELANGgARAN HAM (PERSPEKTIF HUKUM ISLAM) Ikhwan

BMT DAN DEMOKRATISASI EKONOM: MEMBUMIKAN EKONOMI SYARIAH DI INDONESIA Lukman A - H Lkim

DINAMIKA PEMIKIRAN FIQH DALAM NU: ANALISIS ATAS NALAR FIQH POLA MAZHAB Ahmad Arifi

KOMPROMI DAN INTERSEKSIONALITAS GENDER DALAM PEMBERIAN MAHAR: TRADISI AMPA COI NDAI PADA SUKU MBOJO Atun Wardatun 


\section{PEDOMAN TRANSLITERASI}

\begin{tabular}{|c|c|c|c|}
\hline Arab & Latin & Arab & Latin \\
\hline 1 & $=$ & = & $=\mathrm{f}$ \\
\hline ب & $=$ & ق & $=\mathrm{q}$ \\
\hline$\dot{H}$ & ts & ك & $=\mathrm{k}$ \\
\hline 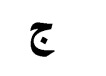 & $=$ & $J=$ & $=1$ \\
\hline$\tau$ & $=$ & b & $=\mathrm{m}$ \\
\hline$\dot{\tau}$ & $=\quad \mathbf{k h}$ & ن & $=\mathbf{n}$ \\
\hline$د$ & $=$ & و & $=\mathbf{w}$ \\
\hline$\dot{j}$ & $\mathrm{dz}$ & $\Delta$ & $=\mathbf{h}$ \\
\hline J & $=$ & $\varepsilon$ & $=$, \\
\hline j & $=$ & 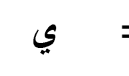 & $=\mathbf{y}$ \\
\hline س & $=$ & & \\
\hline ش ش & $\begin{array}{l}=\quad \text { sy } \\
=\quad \text { sh }\end{array}$ & \multicolumn{2}{|c|}{$\begin{array}{l}\text { Untuk Madd } \\
\text { dan Diftong }\end{array}$} \\
\hline ض & dl & $i$ & $=\hat{a}$ (a panjang) \\
\hline b & th & = & $=\hat{\mathbf{i}}(\mathbf{i}$ panjang $)$ \\
\hline ظ & $\mathbf{z h}$ & أو = & $=\hat{\mathbf{u}}$ (u panjang) \\
\hline$\varepsilon$ & $=$ & آو = & $=\mathbf{a w}$ \\
\hline$\dot{\varepsilon}$ & $=\mathbf{g h}$ & = آين & $=$ ay \\
\hline
\end{tabular}


TransLiterasi

ARTIKEL

Miftahul Huda

Mutawalli

Ikhwan

Kasjim Salenda

Hamid Fahmy

Rusli

Ahmad Arifi

Atun Wardatun
Pemikiran Fiqh

dan Spirit Transformasi Sosial $\bullet$ 1-22

Perspektif Muhammad Sa'îd al-Asymâwî

tentang Historisitas Syari'ah • 23-58

Asas Retroaktif

pada Kasus Pelanggaran HAM

(Perspektif Hukum Islam) • 59-80

Terorisme

dalam Perspektif Hukum Islam • 81-108

Genealogi

Liberalisasi Pemikiran Islam • 109-140

Kontroversi Akhbârî-Ushûlî

dalam Tradisi Pemikiran

Syı̀'ah Imâmiyyah • 141-168

Lukman Al-Hakim

BMT dan Demokratisasi Ekonomi:

Membumikan Ekonomi Syari'ah

di Indonesia • 169-188

Dinamika Pemikiran Fiqh dalam NU:

Analisis atas Nalar Fiqh

Pola Mazhab • 189-216.

Kompromi dan Interseksionalitas Gender dalam Pemberian Mahar: Tradisi Ampa

Co’i Ndai pada Suku Mbojo • 217-236.

\section{INDEKS}




\title{
KOMPROMI DAN INTERSEKSIONALITAS GENDER DALAM PEMBERIAN MAHAR: \\ TRADISI AMPA COI NDAI PADA SUKU MBOJO
}

\author{
Atun Wardatun*
}

\section{Abstract}

Ampa Co’i Ndai is a practiced tradition among Suku Mbojo ${ }^{1}$ (Bimanese ethnic) where the resource of bride-payment is from the brides, wholly or partially, but it is named after the groom during the declaration of marriage contract. The tradition is, usually, applicable if the social, economic, and/or educational status of brides are bigher than that of grooms. Whereas, the ideal expectation of culture and religious norms position men as superior human beings. Gender analysis observes that the tradition is a compromise of the ideal expectation and the real fact of gender relation. In the gender intersectionality's view, the tradition shows that the male-female relationship should not only be explained merely based on the sexual differences but should be examined comprehensively along with other social categories such as economic, social and educational status. Gender status should be seen as a cross-cutting issue which is inseparable with multi identities of human being.

Keywords: Identitas Gender, Idealitas vs Realitas, Ekspektasi Budaya, Doktrin Agama, Kategori Sosial.

FIQH (hukum Islam) telah menentukan bahwa mahar adalah kewajiban laki-laki dan merupakan hak perempuan. ${ }^{2}$ Ketentuan mahar dalam Islam merupakan penghargaan terhadap perempuan dengan memberikan hak memiliki properti pada

*Penulis adalah dosen Fakultas Syari'ah IAIN Mataram Jln. Pendidikan 35 Mataram. email: atunw2004@yahoo.com

1Suku Mbojo adalah nama Suku bagi orang Bima (penduduk bagian paling Timur Nusatenggara Barat dan terletak di pulau Sumbawa).

2Dalam istilah fiqh, padanan kata mahar ini disebut juga dengan shadaq, niblah, dan thaul. Lihat Husein Muhammad, Fiqh Perempuan: Refleksi Kyai atas Wacana Agama dan Gender (Yogyakarta: LKiS, 2001), 109. 
perempuan, ${ }^{3}$ setelah sebelumnya, pada masa Jahiliyyah, perempuan tidak mempunyai hak memiliki, bahkan perempuan menjadi barang yang bisa dimiliki. Sayangnya, nafas awal dari disyariatkannya mahar ini tereduksi oleh adanya kenyataan dan anggapan bahwa mahar dalam Islam justeru untuk membeli perempuan dan mengabsahkan perlakuan apa saja terhadap perempuan. Mahar, sejatinya, adalah simbol dari pemberian hak memiliki kepada perempuan bahwa di dalam kehidupan berkeluarga kelak, perempuan juga berhak untuk memiliki secara pribadi harta mereka. Berbeda dengan masyarakat Barat misalnya yang mengartikan mahar lebih sebagai dowry atau pemberian orang tua perempuan kepada laki-laki (suami) seorang perempuan dengan pertimbangan bahwa harta perempuan beralih dari ayahnya kepada suaminya ketika dia menikah. Perdebatan tersebut mendorong untuk melihat kembali konsep fiqh mengenai mahar. ${ }^{4}$

Terlepas dari pro-kontra tersebut, pemberian mahar yang dimutlakkan sebagai kewajiban laki-laki sebenarnya pada realitas empirisnya bisa dinegosiasi. Dalam kasus tertentu, walaupun secara formalitas mahar dianggap sebagai pemberian laki-laki, secara faktual, misalnya karena status sosial perempuan lebih tinggi dan seorang laki-laki tidak mampu membayar mahar mitsl, ${ }^{5}$ maka seringkali biaya mahar itu sebenarnya berasal dari istri. Tentu saja seseorang berhak untuk mengatakan bahwa hal tersebut seharusnya tidak terjadi jika mahar itu tidak harus mahal

${ }^{3} \mathrm{KH}$. Husein Muhammad, misalnya, menempatkan topik mahar sebagai bagian dari wujud pergaulan yang baik dari laki-laki terhadap perempuan. Lihat bukunya Fiqh Perempuan..., 143-156

${ }^{4}$ Zaitunah Subhan melihat bahwa dalam fiqh, paling tidak ada tiga ketentuan baku terkait mahar: a. mahar harus ada walaupun bentuk dan ukurannya disesuaikan dengan kondisi; b. secara syar'i yang wajib memberikan mahar adalah laki-laki bukan perempuan; c. kalau adat atau kepatutan lokal membolehkan perempuan; memberikan mahar boleh-boleh saja, tetapi bukan merupakan hukum Islam. Lihat Zaitunah Subhan, Menggagas Figh Pemberdayaan Perempuan, (Jakarta: El Kahfi, 2008), 227.

${ }^{5}$ Mahar mitsl adalah mahar sepadan, yaitu mahar yang diberikan sesuai dengan jumlah yang berlaku di keluarga perempuan atau pada budaya masyarakat tersebut. Lihat Sayid Sabiq, Fiqh al Nisâ, Jilid II (Beirut: Dar al Fikr, 1992), 142. 
karena Nabi sendiri telah menitahkan bahwa mahar harus sesederhana mungkin. Akan tetapi, secara faktual banyak sisi yang ikut menentukan tinggi dan rendahnya mahar dalam pernikahan yang pada berbagai masyarakat di Indonesia.

Pada masyarakat suku Mbojo, misalnya, membayar sendiri mahar oleh pihak perempuan atau yang dalam istilah setempat disebut ampa co'i ndai sering terjadi yang disebabkan oleh berbagai macam faktor. Salah satunya adalah terlalu tingginya status seorang istri yang berimplikasi pada tingginya mahar, sementara calon mempelai laki-laki tidak mampu membayar. Faktor lain, misalnya, karena keberhasilan seorang laki-laki meraih gelar pendidikan atau posisi yang tinggi, banyak perempuan, yang karena kecukupan ekonomi, bersedia membayar mahar sekaligus membiayai pesta pernikahan asalkan dia bisa mendapatkan laki-laki tersebut. Sekali lagi biasanya, walaupun mahar ini dibayarkan oleh perempuan, dalam pernyataan ijab qabul secara formal tetap disebutkan bahwa mahar berasal dari laki-laki. Uniknya, walaupun senyatanya mahar itu berasal dari perempuan, mahar tersebut bukan lalu menjadi milik sepenuhnya seorang laki-laki, tetapi kelak tetap menjadi milik perempuan yang biasanya menjadi hak pribadi perempuan. Mahar ini bisa saja digunakan untuk kepentingan personal perempuan atau digunakan secara bersama dengan lakilaki.

Tulisan ini berupaya menggambarkan bagaimana kasus ampa co'i ndai (pembayaran mahar oleh perempuan) yang terjadi pada masyarakat suku Mbojo. Apakah ampa co'i ndai ini merupakan bentuk interseksionalitas gender, yaitu permasalahan gender itu tidak bisa dijelaskan secara terpisah dari faktor-faktor yang lain misalnya faktor status sosial? Ataukah sebenarnya ampa co'i ndai ini adalah sebuah bentuk kompromi terhadap tradisi yang mewajibkan hanya laki-laki yang memberi mahar padahal tidak semua laki-laki mampu melakukannya.

\section{Mahar: Membeli Atau Menghargai?}

Mahar atau dalam bahasa Indonesia disebut maskawin pada dasarnya adalah nama dari sejumlah pemberian yang diberikan oleh laki-laki kepada perempuan karena terjadinya ikatan 
perkawinan. Mahar ini adalah perlambang keseriusan seorang laki-laki mengawini seorang perempuan yang dalam bahasa al Qur'an disebut shadaq. ${ }^{6}$

Istilah lokal masyarakat Mbojo menyebut mahar ini dengan co'i (harga). ${ }^{7}$ Upacara pengantaran mahar disebut wa'a co'i (membawa harga). ${ }^{8}$ Co'i dalam bahasa Bima bermakna harga dalam pengertian material atau uang misalnya dalam kalimat sabune co'i barangke sabua? (berapa harga barang ini?) maupun dalam arti harga yang berkonotasi menghargai secara immaterial, misalnya dalam ungkapan dou re harus di ka-co'i (orang itu harus dihargai). Dengan demikian, co'i sebagai sebutan mahar ini dapat bermakna kedua-duanya, baik harga dalam arti materi karena memang ada barang atau uang yang diberikan sebagai wujud adanya mahar dan juga dalam arti immateri karena pemberian tersebut ditujukan sebagai perlakuan menjunjung tinggi. Lalu muncul pertanyaan, apakah mahar itu secara substansi membeli atau menghargai?

Praktek membeli dilakukan ketika ada barang yang dibayar dengan nilai material baik berupa uang maupun berupa barter sesama benda. Pada praktek menghargai, pemberian terhadap seseorang bukan semata-mata dipandang pada nilainya, tetapi pada arti substansial di balik pemberian itu. Oleh karena itu, dalam menghargai bisa saja secara material sesuatu yang diberi

${ }^{6}$ Dalam teks ayat mahar yang terdapat dalam Qs. Al-Nisa(4): 4 jelas dikatakan bahwa mahar itu berasal dari laki-laki dengan perintah-Nya "berikanlah perempuan maharnya dengan kerelaan hati.". Departemen Agama RI, Al-Qur'an dan Terjemahnya (Semarang: Toha Putra, 1989), 115.

7Di daerah Tapanuli Selatan dan Sumatera Selatan ada istilah "Jujur" yaitu pemberian yang serupa dengan mahar tetapi tidak sama persis. Pemberian ini dari kerabat laki-laki kepada kerabat perempuan yang dimaksudkan sebagai lambang memasukkan perempuan dan anak-anak yang dilahirkannya kelak kepada klan bapaknya. Lihat Iman Sudiyat, Hukum Adat: Sketsa Asas, cet. II (Yogyakarta: Liberty, 1987), 110-11.

${ }^{8}$ Mahar ini bisa berupa uang atau juga rumah lengkap dengan isinya ataupun hewan ternak. Biasanya di beberapa desa di Bima dulu mahar berbentuk rumah jati yang komplit bersama sisi dan peralatannya. Rumah jati ini berukuran 6 tiang, 9 tiang, atau 12 tiang. Banyaknya tiang ini menandakan besar kecilnya rumah tersebut. Lihat Fachrir Rahman, Islam di Bima: Kajian Historis tentang Proses Islamisasi dan Perkembangannya Sampai Masa Kesultanan (Yogyakarta: Genta Press, 2009), 33. 
tidak bernilai apa-apa, tetapi merupakan indikasi penghormatan dan penjunjungan terhadap seseorang. Dalam prakteknya, menghargai ditunjukkan dalam bentuk sikap, perkataan, perbuatan atau juga barang yang bernilai tinggi maupun rendah bergantung pada konteks apa penghargaan itu diberikan. Misalnya, piagam penghargaan sesungguhnya tidak bernilai apaapa dan tidak bisa dijual, tetapi itu mempunyai arti penghargaan terhadap prestasi. Pada masyarakat suku Mbojo, misalnya ada praktek yang disebut lia angi, yaitu mempertuakan orang yang lebih tua dengan cara memanggil bukan dengan nama aslinya, tetapi dibolak-balik, misalnya, Ahmad menjadi Hima, Mariam menjadi Rao. Cara pemanggilan seperti itu adalah dalam kerangka menghargai. Akan halnya dengan mahar, nampaknya dalam praktek masyarakat Mbojo bukan semata-mata dalam arti membeli, tetapi lebih berkonotasi pada menghargai.

Konotasi mahar pada arti menghargai tampak pada fleksibilitas masyarakat Mbojo yang tidak secara kaku mengharuskan mahar itu dari pihak laki-laki. Nurhilaliati' melihat paling tidak ada tiga macam sumber mahar yang dilakukan dalam praktek pernikahan masyarakat Mbojo; pertama, mahar dari pihak laki-laki yaitu ketika pihak laki-laki, memang orang yang berada dan sanggup menyesuaikan juga dengan status sosial pihak perempuan. Kedua, mahar yang ditalangi bersama, baik oleh pihak laki-laki maupun perempuan, misalnya ketika kedua belah pihak sama-sama berada pada posisi sosial ekonomi yang sama. Ketiga, mahar dari perempuan, tetapi diatasnamakan pihak lakilaki. Kasus kedua dan ketiga inilah yang dinamakan dengan ampa co'i ndai. Jadi, dalam ampa co'i ndai bisa terjadi sebagian atau seluruh mahar ditanggung oleh perempuan.

Menariknya, walaupun dalam praktek faktualnya, sumber mahar bisa beragam seperti ini, dalam aqad nikah, pernyataan pemberian mahar tetap dinyatakan secara tegas bersumber dari laki-laki. Nampak dari kasus ini bahwa mahar seringkali bermakna prestise terutama prestise pihak perempuan karena dalam acara aqad nikah, jumlah mahar disebutkan dan diumumkan

'Nurhilaliati, "Perempuan dan Mahar" dalam Menolak Subordinasi, Menyeimbangkankan Relasi: Beberapa Catatan Reflektif Seputar Islam dan Gender (Mataram: PSW IAIN Mataram Press, 2007), 60-3. 
secara terang-terangan sehingga walaupun mahar itu senyatanya berasal dari perempuan, tetap diatasnamakan sebagai pemberian laki-laki. Tampak di sini; bahwa secara legal formal dan ideologis, masyarakat Mbojo tetap menolak kebolehan perempuan berkontribusi atau memberikan mahar. Pemberian mahar pada ampa'co'i ndai ini bisa diterima bukan karena alasan keperempuanan seseorang yang memberikan, tetapi karena kebetulan statusnya mengharuskan dia untuk berkontribusi.

Menurut tokoh agama setempat, ${ }^{10}$ ampa co'i ndai ini merupakan dialog antara pemahaman agama dan konteks lokal. Dalam Islam, mahar secara tegas disebutkan sebagai pemberian laki-laki kepada perempuan. Padahal, kenyataannya laki-laki juga ada yang tidak mampu menunaikannya. Oleh, karenanya, bargaining yang bisa dilakukan sebagaimana hadis Nabi yang mengatakan bahwa cincin dari besi pun bisa diberikan sebagai mahar adalah pada jumlah kuantitas mahar bukan tentang siapa yang memberi. Sementara itu, kondisi lokal Mbojo melihat bahwa prestise seorang perempuan tidak bisa dihargai secara sederhana dan "apa adanya". Oleh karena itu, harus tampak adanya harga yang "layak" untuk seorang perempuan. Untuk mengkompromikan ketidakmampuan laki-laki di satu sisi padahal ingin mempertahankan gengsi dan tuntutan prestise perempuan di sisi lain tersebut, mahar tetap disebutkan, seakanakan, bersumber dari pihak laki-laki. Namun, bisa jadi sebagian atau seluruh mahar tersebut berasal dari pihak perempuan yang kemudian menjadi hak milik perempuan.

Ketentuan mahar yang tidak kaku dalam Islam pun ${ }^{11}$ mengindikasikan bahwa mahar bukan merupakan harga mutlak yang tidak bisa ditawar dalam pengertian membeli, tetapi lebih sebagai simbol dari penghargaan terhadap perempuan yang tidak bisa dinilai secara material. Simbol ini mengawali bagaimana kelak dalam kehidupan keluarga, perempuan bukan merupakan

10Wawancara dengan H. Abdullah H. Usman, tanggal 27 September 2009.

${ }^{11}$ Dalam salah satu hadisnya, Nabi saw. bersabda yang artinya: "Keberkatan paling agung dari suatu perkawinan adalah maskawin yang mudah/ringan untuk diberikan". Lihat Ahmad ibn Hanbal, al Musnad, Juz VI, 82. 
hak properti laki-laki, tetapi justeru memiliki hak properti yang bebas ia pergunakan untuk kepentingannya sendiri. Oleh karena itu, nilai substansi dari mahar adalah menghargai perempuan, perlambang hak kepemilikan, dan independensi ekonomi perempuan. $^{12}$

Nilai mahar atau co'i ketika dipandang sebagai membeli atau menghargai memiliki implikasi yang berbeda. Jika mahar dianggap sebagai membeli, perempuan dipandang sebagai pihak yang dimiliki oleh yang membeli atau pihak laki-laki. Sebaliknya, pihak perempuan akan menawarkan harga tertentu yang tidak bisa diganggu gugat. Lebih jauh Muslihun melihat bahwa ketika aqad nikah dibelokkan menjadi aqad tijârah (perjanjian jual beli), maka berakibat mempengaruhi hubungan suami istri di dalam rumah tangga sebagai tuan di satu pihak dan hamba di pihak lain, cenderung terjadi superioritas suami yang berlebihan. ${ }^{13}$ Jika mahar diartikan membeli, yang terutama di situ adalah nilai materi yang dihitung berdasarkan logika untung rugi. Sedangkan jika mahar diartikan sebagai menghargai, berapa nilai materi tidaklah terlalu penting. Yang signifikan adalah arti di balik pemberian itu yang diharapkan menjadi titik awal terjadinya relasi yang lebih egaliter antara suami dan istri atas dasar saling menghargai.

\section{Ketentuan Mahar Dalam KHI}

Kompilasi Hukum Islam (KHI) mengatur permasalahan mahar ini dalam bab tersendiri, yaitu Bab V (pasal 30-38). Beberapa prinsip tentang mahar yang diatur dalam KHI adalah sebagai berikut:

a. Mahar adalah kewajiban laki-laki (pasal 30) yang diberikan langsung kepada perempuan untuk menjadi hak pribadinya

${ }^{12}$ Bandingkan dengan pendapat Zaitunah Subhan dalam Subhan, Menggagas... , 226. Sayid Sabiq juga melihat bahwa mahar adalah lambang cinta dan kasih sayang seorang laki-laki terhadap perempuan, Lihat Sabiq, Fiqh..., 135.

${ }^{13}$ Lihat Muslihun, "Relasi Suami dan Istri berdasarkan Nash (Studi Kasus Masyarakat Muslim Sasak)" dalam Menolak Subordinasi Menyeimbangkan Relasi: Beberapa Catatan Reflektif Seputar Islam dan Gender (Mataram: PSW IAIN Mataram Press, 2007), 78. 
(pasal 32). Berdasarkan prinsip ini, mahar itu bukan milik atau hak wali/orang tua/keluarga dan pemberiannya tidak memerlukan pihak ketiga, tetapi secara langsung dari pihak laki-laki kepada pihak perempuan walaupun dalam aqad ijab qabul dilakukan oleh mempelai pria dan wali.

b. Bentuk dan jenis mahar disepakati kedua belah pihak (pasal 30), tetapi berdasarkan asas kesederhanaan dan kemudahan (pasal 31). Prinsip ini bermakna bahwa mahar itu memang merupakan simbol penghargaan bukan pembelian. Dalam membeli, harga telah ditetapkan sepihak oleh penjual walaupun ada tawar menawar, maka itu tidak bisa kurang dari harga yang telah dipatok oleh penjual. Dalam penentuan mahar yang berlaku di masyarakat Bima, misalnya, ketentuan mahar itu belum bisa diketahui pasti sebelum terjadi kesepakatan. Asas kesederhanaan dan kemudahan itu sendiri mengandung arti bahwa dalam penentuan mahar itu perlu memperhatikan kondisi kedua belah pihak. Pihak perempuan tidak boleh semata-mata karena alasan prestise sehingga mereka mengenyampingkan kondisi laki-laki. Hal ini juga demi mengurangi beban laki-laki sehingga tanggung jawab mereka lebih ringan. Memaksakan beban yang tidak bisa dipikul oleh laki-laki atas dasar asumsi bahwa semua laki-laki pasti mampu meberikan mahar sesuai dengan keinginan perempuan adalah pandangan yang bias. Bias gender, pada kenyataannya, bisa merugikan kaum perempuan dan laki-laki.

c. Mahar walaupun wajib, tetapi bukan rukun perkawinan (pasal 34). Rukun perkawinan harus menyertai proses perkawinan karena kalau salah satunya saja tidak ada maka perkawinan tersebut tidak akan terjadi. Misalnya, jika calon istri tidak ada, maka dengan siapakah calon suami akan menikah? Mahar walaupun wajib diberikan, tetapi ketika terjadi pernikahan bisa saja tidak dibayar tunai dan hal tersebut tidak mempengaruhi sahnya perkawinan. Demikian pula jika terjadi kelalaian menyebutkan jumlah mahar pada waktu menikah, kelalaian itu tidak sampai membatalkan pernikahan (pasal 34 ayat 2). Berbeda ketika calon mempelai laki-laki salah menyebut nama calon mempelai perempuan yang merupakan salah satu dari rukun perkawinan demikian 
pula jika wali salah menyebutkan nama calon mempelai lakilaki. Kelalaian tersebut mempengaruhi sahnya perkawinan karena harus jelas nama dan identitas orang yang akan dinikahkan.

d. Mahar tetap harus dibayar setengahnya ketika terjadi perceraian karena talak sebelum adanya hubungan seksual (pasal 35 ayat 1), sedangkan jika suami meninggal sebelum adanya hubungan seksual, mahar tetap menjadi hak penuh istri. Jika mahar berarti membeli, ketika perempuan belum dimiliki, yang ditandai dengan telah terjadinya hubungan badan, perempuan belum berhak untuk mendapatkan "harga". Bandingkan dengan aqad jual beli yang tidak bisa terjadi jika salah satu pihak sengaja atau tidak sengaja memutuskan kesepakatan untuk membeli. Biasanya dalam hal seperti itu perjanjian jual beli tidak bisa dilakukan.

Tampak dari aturan KHI tersebut bahwa mahar memang harus berasal dari laki-laki. KHI sebagai formulasi hukum Islam yang telah dikontekskan dengan tradisi Indonesia memandang bahwa laki-laki memang harus bertanggung jawab penuh bagi kewajiban finansial, baik berupa mahar maupun nafkah. ${ }^{14}$ Oleh karena itu, baik agama maupun budaya memang melihat laki-laki sebagi pihak satu-satunya yang wajib menyediakan dan memberikan mahar untuk perempuan

\section{Kasus Ampa Co'i Ndai}

Ampa co'i ndai secara bahasa bermakna mengangkat harga sendiri (ampa: mengangkat, co' $i$ : harga, ndai: saya atau sendiri). Istilah ampa co'i ndai ini secara khusus dalam penggunaanya berarti membayar mahar sendiri. Dalam hal ini pihak perempuan membayar maharnya sendiri, tetapi diatasnamakan pihak laki-laki dalam ikrar akadnya. Sebagaimana tergambar dari arti kata per kata dari ampa co'i ndai, kontribusi mahar dari pihak perempuan ini bermaksud mengangkat prestise perempuan agar tidak malu menikah tanpa atau dengan sedikit mahar. Biasanya kesepakatan

${ }^{14}$ Mengenai bagaimana KHI mendikhotomikan tanggung jawab publik yang ekonomis dan tanggung jawab domestik yang nonekonomis, lihat Atun Wardatun, Negosiasi Ruang: Antara Runag Publik dan Domestik (Mataram: PSW IAIN Mataram Press, 2007). 
dibayarnya mahar oleh pihak perempuan ini adalah kesepakatan internal dari kedua keluarga tanpa melibatkan pihak luar karena ampa co'i ndai ini biasanya dilakukan untuk menjaga harga diri atau prestise keluarga perempuan di hadapan masyarakat luas. Walaupun ampa co'i ndai ini berarti perempuan membayar maharnya sendiri, uniknya, sumber uang atau benda pembayaran tersebut tidak selalu berasal dari milik pribadi perempuan tetapi bisa juga dari pemberian orang tua atau kerabatnya.

Berikut ini gambaran kasus ampa co'i ndai yang terjadi pada masyarakat Mbojo. ${ }^{15}$ Data-data yang dipaparkan di sini diperoleh melalui wawancara mendalam terhadap para pelaku ampa co'i ndai. Para pelaku ampa co'i ndai tersebut diperlakukan sebagai sumber data primer, sedangkan sumber data sekunder diperoleh dari wali maupun saksi pernikahan serta tokoh agama dan tokoh masyarakat yang bisa memberikan informasi yang diinginkan. Penentuan informan yang diwawancarai ditentukan secara purposive yaitu mereka yang bisa memberikan data yang dicari terkait dengan personal story dari kasus ampa co'i ndai.

\section{Calon Istri bergelar Magister}

Hayati dan Muslih adalah sepasang kekasih yang baru bertemu. Pertemuan mereka di sebuah acara pernikahan teman cukup berkesan sehingga mereka saling jatuh cinta. Jatuh cinta pada pandangan pertama itu berlanjut dan mereka melangkah lebih maju untuk saling mengenali lebih jauh identitas, karakter, latar belakang keluarga, dan pekerjaan masing-masing.

Setelah beberapa bulan menjalin hubungan, Muslih dan Hayati sudah cukup mempunyai informasi tentang pasangan mereka. Karakter mereka cocok, Muslih yang cenderung bisa melucu bisa mencairkan suasana berhadapan dengan Hayati yang kalem dan introvert. Latar belakang keluarga yang berbeda pun tidak menjadi kendala bagi mereka. Hayati yang berkeluarga guru dan Muslih yang berkeluarga pegawai kantoran tampaknya bisa saling mengisi. Mereka juga sama-sama bekerja sebagai PNS walaupun pendapatan Muslih sebagai pegawai di sebuah bank

${ }^{15}$ Untuk alasan kerahasiaan (confidentiality) nama-nama yang disebut dalam paparan kasus ini bukan nama asli. 
swasta jauh lebih tinggi daripada Hayati yang hanya seorang guru. Satu-satunya masalah adalah bahwa Hayati berpendidikan lebih tinggi daripada Muslih. Sebagai praktisi, Muslih hanya bergelar sarjana S1, sedangkan keinginannya untuk terus meningkatkan ilmu sebagai guru, Hayati telah meraih gelar magister.

Hayati hanya dua bersaudara dengan kakak perempuannya yang berprofesi dosen, sedangkan Muslih masih memiliki banyak adik dan tanggungan apalagi ia merupakan tulang punggung keluarga setelah ayahnya meninggal. Praktis, walaupun pendapatan bulanannya tinggi, Muslih hampir jarang ber "senang-senang" dengan kebutuhannya sendiri karena ia harus mengongkosi kuliah adik-adiknya.

Kondisi Muslih yang masih belum mapan dan berpendidikan lebih rendah dari Hayati inilah yang membuat Muslih tidak percaya diri untuk segera melamar Hayati. Di lain pihak, Hayati dan keluarganya menaruh hati dan harpan terhadap Muslih. Mereka melihat Muslih mampu menjadi imam bagi Hayati membentuk keluarga yang sakinah.

Muslih masih ragu-ragu untuk maju. Cintanya terhadap Hayati sebenarnya sangat mendalam, tetapi ia ragu jangan-jangan ia tidak mampu mencukupi kebutuhan materi Hayati dan tingkat pendidikan mereka yang berbeda kelak menjadi batu masalah dalam kehidupan keluarganya. Dalam kondisi seperti ini, keluarga Muslih juga mencoba-coba menawarkan Muslih perempuan lain dari keluarga sendiri yang kira-kira se"kufu" dengan Muslih.

Adanya kemungkinan lain menyebabkan Hayati dan keluarganya khawatir. Mereka tidak ingin kehilangan Muslih. Hayati pun berusaha meyakinkan Muslih bahwa perbedaan latar belakang keduanya tidak akan menjadi masalah selama kedua belah pihak tersebut saling mengerti. Muslih pun bisa menerima. Masalah selanjutnya adalah Muslih belum punya cukup modal untuk mahar dan biaya pesta pernikahan.

Hayati menginginkan pernikahan dipercepat dan masalah mahar serta biaya pernikahan bisa dinegosiasikan. Yang penting ada keinginan kuat dari Muslih untuk segara mengikatkan secara sah hubungan mereka. Negosiasi pun dilakukan. Keputusannya, 
keluarga Muslih membawa apa yang mereka miliki tanpa tuntutan dari pihak Hayati dan kekurangannya bisa ditutupi oleh keluarga Hayati baik untuk pesta pernikahan yang memang dilaksanakan pada tempat perempuan maupun untuk mahar yang akan diikrarkan pada acara akad.

\section{Calon Istri Berada dan Keluarga Terpandang}

Wahidah dan Zainal adalah teman kuliah yang menjalin hubungan pada semester akhir perkuliahannya. Sebelumnya mereka menjalin hubungan dengan orang lain dan masingmasing mereka mengetahui. Akan tetapi ketidakcocokan membuat mereka tidak bisa melanjutkan hubungan dengan ex masing-masing.

Hubungan Wahidah dan Zainal terjalin ketika Wahidah menyusun skiripsi. Zainal yang memang termasuk mahasiswa cerdas dan berprestasi selalu menjadi tempat rujukan bagi teman-temannya ketika merasa kesulitan dengan tugas perkuliahan. Wahidah pun tidak ketinggalan memanfaatkan kepintaran Zainal. Hubungan mereka yang intens dari hubungan membantu ini lambat laun menjadi hubungan cinta. Zainal sendiri konon jatuh cinta kepada Wahidah karena karakternya yang sabar dan berasal dari keluarga terpandang. Ketika pertama kali mendatangi tempat (kamar) kontrakan Wahidah, Zainal merasa jatuh cinta melihat foto keluarga besar mereka yang menurut Zainal merupakan gambaran keluarga berhasil dan berwibawa.

Demikianlah, awal cerita cinta mereka yang tetap berlanjut sampai Zainal diangkat menjadi dosen di almamaternya. Zainal tentu sudah siap meminang gadis pilihan. Demikian pula Wahidah sudah tidak sabar bersanding dengan pria idamannya. Permasalahannya, Zainal belum siap secara materi untuk melangkah ke jenjang itu.

Wahidah berasal dari keluarga besar dan bapaknya adalah seorang pejabat yang juga tokoh agama yang sangat berpengaruh. Ia juga anak pertama perempuan yang akan dinikahkan karena empat kakak sebelumnya laki-laki. Orang tua Wahidah dan keluarga tentu menginginkan pesta yang meriah dan mahar yang sepadan (mahar mits) untuk pernikahan 
Wahidah. Sedangkan, Zainal berasal dari keluarga pas-pas-an. Walaupun jumlah saudara kandungnya juga banyak, hanya Zainal yang sempat meraih pendidikan tinggi karena keadaan ekonomi keluarga. Praktis, Zainal juga adalah tumpuan harapan keluarga.

Singkat cerita, pernikahan berlangsung dengan kesepakatan nanti mahar yang akan diikrarkan pada acara ijab qabul adalah seperangkat alat shalat dan 15 gram emas. Zainal bisa mengupayakan seperangkat alat shalat tetapi 15 gram emasnya ditanggung oleh Wahidah. Demikian pula sebagian besar biaya pernikahannya, ditanggung oleh Wahidah. Mereka kini hidup sederhana dan bahagia dengan seorang putri yang, pada saat wawancara, masih berumur 3 bulan.

\section{Calon Istri Lebih Tua daripada Calon Suami}

Nuraini adalah seorang guru MI swasta yang sudah mengabdi sebagai PNS selama hampir 10 tahun. Usianya sudah 30-an tahun, tetapi belum juga menemukan orang yang tepat menjadi pendampingnya.

Nur sebenarnya punya masa lalu yang cukup menyakitkan. Lima tahun yang lalu ia pernah dilamar oleh kekasihnya yang sudah ia pacari selama 3 tahun. Upacara lamaran tersebut sebenarnya cukup meriah. Keluarga besar dari pihak laki-laki dan pihak perempuan berkumpul dan bersepakat untuk menyatukan tali keluarga mereka. Akan Tetapi, entah mengapa sebulan kemudian, kekasihnya sudah jarang berkomunikasi dan bersilaturrahmi dengannya. Belakangan, Nur mendengar dari beberapa kerabat kekasihnya karena orang tua kekasihnya menerima kabar yang tidak baik tentang Nur. Hubungan mereka berakhir karena fitnah yang tidak diklarifikasi.

Kejadian itu membuat Nur lebih berhati-hati memilih calon pendamping. Sampai suatu ketika seorang guru honorer masuk mengabdi di MI tempat Nur mengajar. Guru baru yang usianya lebih muda 7 tahun dari Nur itu ternyata mampu menarik hati Nur. Usianya yang muda ternyata bukan halangan bagi Syamsuddin, nama guru muda itu, untuk bersikap dewasa. Cinta Nur ternyata tidak bertepuk sebelah tangan. Syamsuddin juga menaruh hati terhadap Nur. Syamsuddin yang sejak kecil telah 
ditinggal mati oleh ibunya dan merupakan anak sulung dari 3 bersaudara ternyata mendambakan perhatian dan kasih sayang dari seorang perempuan yang lebih tua daripadanya. Latar belakang ini ternyata berpengaruh juga pada kriteria Syam mencari pendamping hidup.

Singkat cerita, terjalinlah hubungan mereka dan mereka sepakat untuk menapaki jenjang yang lebih serius, yaitu menikah. Permasalahan muncul ketika Syam menyadari bahwa ia belum mampu menanggung pesta dan mahar pernikahan mereka. Syam yang guru honorer tentu mempunyai pendapatan yang sangat pas-pasan. Selain itu, keluarga juga khawatir, masyarakat menganggap aneh hubungan mereka yang berbeda dari kebiasaan umum. Syam jauh lebih muda daripada Nur. Banyak teman-temannya berusaha mempengaruhinya bahwa menikah dengan perempuan yang lebih tua lebih banyak ruginya karena Syam hanya akan mengecap manisnya sebentar mengingat perempuan punya masa menopause.

Urusan lebih muda dan menopause tidak menjadi masalah bagi Syam. Pernikahan memiliki banyak aspek yang tidak bisa disederhanakan hanya dari aspek seksual walaupun seksualitas tentu penting di dalam pernikahan. Syam juga yakin bahwa usia tidak menjadi jaminan kedewasaan. Usia adalah masalah kuantitas, tetapi kualitas seseorang tidak hanya ditentukan oleh faktor usia. Nur juga meyakini hal yang sama.

Syam hanya terutama cemas dengan kondisi perekonomiannya. Sebagai calon suami yang katanya harus menjadi "pemimpin" Syam merasa tidak siap untuk menikah dan menjadi pihak yang memberi. Ia khawatir tidak bisa membahagiakan Nur dan keluarganya. Nur, sebaliknya, tidak mengaggap kekurangan dana ini sebagai problem. Nur siap untuk menanggung biaya pernikahan maupun mahar dari tabungannya sendiri. Nur juga tidak menuntut mahar yang tinggi seperti kebiasaan di kampungnya.

Syam dan Nur tidak ingin pernikahan mereka batal atau ditunda. Mereka berdua berfikir keras bagaimana caranya agar pernikahan secepatnya dilaksanakan. Satu-satunya permasalahan adalah masalah keuangan. Muncul ide dari Nur untuk mengambil alih biaya pernikahan dan mahar itu untuk 
ditanggung oleh dia dan keluarganya. Awalnya Syam berkeras menolak karena hal ini terkait dengan "harga dirinya" juga sebagai laki-laki. Akan tetapi, mengingat kondisi dan setelah diyakinkan oleh Nur, Syampun akhirnya menerima. Pernikahan mereka pun terlaksana atas biaya dan mahar sepenuhnya dari keluarga Nur.

\section{Ampa Co’i Ndai: Kompromi dan Interseksionalitas Gender}

Mencermati kasus ampa co'i ndai sebagaimana yang dipaparkan di atas, terungkap bahwa ada dua hal yang bisa digarisbawahi sebagai bahan analisis lebih lanjut.

\section{Tradisi Kompromi.}

Paling tidak, terdapat 3 bentuk kompromi idealitas dan realitas di dalam kasus ampa co’i ndai, yaitu kompromi antara lakilaki dan perempuan, kompromi agama dan budaya, serta antara status sosial dan kewajiban/hak personal.

Ampa co'i ndai ini adalah upaya mengkompromikan kepentingan kedua belah pihak yang akan melangsungkan pernikahan. Laki-laki oleh agama dan budaya dibebani dengan tugas yang lebih bernilai produktif dan ekonomis sehingga mereka adalah pihak yang harus menanggung biaya pernikahan dan mahar. Dalam realitasnya, idealitas harapan budaya dan norma agama ini tidak selalu bisa dilaksanakan. Faktanya, ada laki-laki yang karena berbagai faktor tidak bisa memenuhi tuntutan itu. Oleh karena itu, perempuan menginisiasi dan atau justeru berkontribusi dalam pengadaan mahar itu, baik sebagian atau keseluruhan. Ampa co'i ndai menjadi sebuah kearifan lokal yang telah lama dipraktekkan pada masyarakat Mbojo walaupun terkesan under cover untuk mengurangi dan menegosiasikan beban ini. Inilah yang disebut kompromi yang terjadi antara laki-laki dan perempuan; kedua belah pihak menegosiasikan hak dan kewajiban masing-masing.

Kompromi agama dan budaya yang dimaksud terjadi ketika di satu sisi agama menjadikan mahar sebagai kewajiban mutlak laki-laki. Di sisi lain, ada persoalan budaya ketika seorang perempuan pada lokalitas Mbojo tidak bisa dihargakan "hanya" dengan cincin besi atau mengajarkan al Qur'an sebagaimana 
yang diamanatkan oleh hadis. Pertautan normatif agama dan historis budaya ini kemudian melahirkan pola tertentu yang terejawantah dalam ampa co'i ndai sehingga ada celah bagi perempuan untuk ikut berkontribusi pada pengadaan mahar. ${ }^{16}$ Ideologi agama diselamatkan melalui pengatasnamaan mahar kepada laki-laki, tetapi perilaku keagamaan berusaha mengompromikan ideologi tersebut dengan memberikan kesempatan "tersembunyi" bagi perempuan untuk berkontribusi dalam mahar.

Kewajiban personal seorang laki-laki pun dikompromikan atas dasar posisi atau status sosialnya yang notabene berada di "bawah" status sosial seorang perempuan. Demikian pula hak perempuan bisa dinegosiasikan karena status sosialnya. Mahar lalu tidak dilihat sebagai kewajiban mutlak salah satu pihak dan hak mutlak pihak lain tetapi dapat dinegosiasi kembali berdasarkan posisi masing-masing

Ketiga jenis kompromi tersebut juga menggambarkan bagaimana kesenjangan idealitas dan realitas selalu tidak terhindarkan. Kesenjangan tersebut, dalam batas-batas tertentu, perlu dijembatani sehingga melahirkan model atau cara tertentu pula di dalam sebuah masyarakat. Cara itu tidak selalu disepakati secara verbal dalam bentuk kesepakatan lisan atau tertulis, tetapi terejawantah di dalam praktek yang dilakukan. Cara ampa co'i ndai, misalnya, walaupun menjadi sesuatu yang hidden, masyarakat seakan menyepakati bahwa inilah mekanisme yang berupaya mencairkan kebuntuan "idealitas" ekspektasi seorang laki-laki sebagai pemberi dan perempuan sebagai penerima dan realitas sebaliknya yang tidak jarang ditemui dalam kehidupan nyata. Pendeknya, ampa co'i ndai adalah sebuah kearifan lokal yang berbentuk tawaran solutif ketika terjadi kebuntuan antara harapan dan kenyataan baik yang bersifat personal maupun pada tataran yang lebih makro semisal ekspektasi budaya dan normativitas agama.

\footnotetext{
${ }^{16}$ Catatan ini tidak berpretensi menilai kasus ampa co'i ndai sebagai benar atau salah sebagaimana biasanya cara pandang keagamaan mengambil bentuk, tetapi hanya ingin memberikan catatan-catatan kecil terhadap kearifan ampa co'i ndai pada masyarakat Mbojo.
} 


\section{Interseksionalitas Gender}

Gender intersectionality ${ }^{17}$ atau interseksionalitas gender yang dimaksud adalah bahwa isu gender, baik pada tataran wacana maupun praktis, selalu bersentuhan dengan isu-isu dasar klasifikasi dan keragaman lainnya semisal klasifikasi berdasarkan status sosial, tingkat ekonomi, etnis, ras, warga negara, tingkat pendidikan, kecacatan atau ragam-ragam lainnya. Inilah yang populer disebut sebagai cross-cutting issues. ${ }^{1}$

Interseksionalitas gender memutlakkan pembahasan relasi antara laki-laki dan perempuan tak terlepas dari isu-isu keragaman lainnya. Hal ini untuk menghindarkan terjadinya generalisasi semua laki-laki atau semua perempuan ke dalam klasifikasi yang seragam. ${ }^{19}$ Laki-laki miskin dan tidak berpendidikan tentu tidak sama dengan laki-laki kaya dan berpendidikan. Perempuan berdarah biru tentu tidak sama kondisinya dengan perempuan dari keturunan biasa. Ketika lakilaki yang status sosialnya lebih rendah, misalnya, bertemu dengan perempuan yang berstatus sosial di atasnya, relasi antara mereka tidak hanya bisa dijelaskan dari perspektif gender an-

${ }^{17}$ Konsep gender intersectionality pada awalnya muncul dari aliran multicultural feminism yang memproyeksikan gerakannya pada hubungan erat isu diskriminasi gender dengan isu diskriminasi rasial, etnis, dan kelas. Menurut aliran ini, sistem opresi yang berlaku di dalam suatu masyarakat tidak berunsur tunggal, tetapi selalu mengandung berbagai unsur yang saling berkaitan atau yang mereka sebut sebagai intertwined system of oppression. Lebih jauh tentang aliran feminis multikulturalisme, lihat Judith Lorber, Gender Inequality: Feminist Theories and Politics (California: Roxbury Publishing Company, 2001), 147-62.

${ }^{18}$ Cross-cutting issues of gender ini juga mengilhami wacana maupun praktis gerakan gender di Indonesia. Proyek desiminasi gender pada program PGMI sebagai kerja sama LAPIS Australia dan Depag, misalnya, memodulkan konsep GSI (Gender-Social Inclusion) yang sedikit banyak merupakan wujud dari kesadaran bahwa gender adalah bagian dari kategori sosial yang perlu dibahas secara berkaitan dengan kategori-kategori sosial lainnya.

${ }^{19}$ Kesadaran akan keragaman perempuan dan keharusan melihat partikularitas dan lokalitas perempuan menurut Mohanty adalah kebutuhan penting dalam politik gerakan perempuan: "the urgent political necessity of forming stratgic coalitions across class, race, and national boundaries" dalam Chandra Talpade Mohanty, Feminism without Borders: Decolonizing Theory Practicing Solidarity (Durham\&London: Duke University Press, 2003), 18. 
sich. Relasi yang terjadi di antara mereka tentu juga diwarnai oleh status sosial mereka. Inilah yang dimaksud dengan interseksionalitas gender. Contoh lain, perempuan dari dunia maju yang tidak pernah terjajah dengan perempuan dunia ketiga yang pernah dijajah tentu tidak bisa dijelaskan dengan sama persis. Latar belakang juga menyumbang sesuatu terhadap kondisi kekinian mereka. ${ }^{20}$ Lalu, bagaimanakah menjelaskan interseksionalitas gender ini dalam kasus ampa co'i ndar?

Budaya patriarchy telah lazim melihat bahwa kehidupan ini hierarkhis dan laki-laki harus selalu berada di atas sedangkan perempuan di bawah. Laki-laki harus selalu memberi dan perempuan adalah pihak yang diberi. Kenyataannya, hierarkhi semacam itu tidak selalu terjadi karena posisi bisa saja terbalik. Posisi seseorang tidak saja ditentukan oleh jenis kelamin, tetapi juga oleh aspek-aspek lain yang juga integral dengan kehidupannya. Pada kasus-kasus ampa co'i ndai sebagaimana yang terpapar sebelumnya, posisi pihak perempuan lebih tinggi dalam persepsi sosial baik karena tingkat pendidikan (kasus Hayati), status keluarga (kasus Wahidah), maupun karena usia dan kemapanan (kasus Nuraini).

Perempuan yang memiliki status lebih tinggi baik karena posisi sosial, pendidikan, ekonomi maupun aspek lain dianggap "aneh" (baca: luar biasa) sehingga laki-laki sering merasa berjarak dengan mereka. Ketika hubungan antara perempuan dan lakilaki yang berbeda status ini terjadi, laki-laki merasa tidak yakin (tidak percaya diri) untuk menjalin hubungan yang lebih serius. Hal ini disebabkan oleh harapan budaya dan doktrin agama yang mengharuskan (baca: membebankan) laki-laki sebagai pemegang

\footnotetext{
${ }^{20}$ Interseksionalitas gender ini juga merupakan konsep yang berupaya untuk menghindarkan bias ketika melihat perempuan. Gerakan feminisme atau gerakan gender seringkali bias, misalnya, dengan cara pandang ethnocentrisme bahwa perjuangan perempuan di Barat bisa langsung di copypaste ke wilayah dunia lain. Hal ini tentu tidak benar karena partikularitas selalu lahir pada konteks yang berbeda. Perempuan Arab tidak sama dengan perempuan Indonesia atau perempuan Amerika. Perempuan Jawa berbeda dengan perempuan Sunda. Perempuan Lombok, Bima, dan Sumbawa memiliki karakteristik yang berbeda. Partikularitas itu perlu dihargai dan salah satunya adalah dengan menggunakan perspektif interseksionalitas gender.
} 
posisi yang lebih tinggi. Konflik antara apa yang seharusnya dan senyatanya ini tentu memerlukan jalan keluar, misalnya ketika laki-laki ternyata tidak mampu menjadi pihak penyedia mahar maka ada alternatif yang menjadi solusi, yaitu dengan cara ampa co’i ndai.

Pada kasus ampa co'i ndai ini, kenyataan bahwa Hayati, Wahidah, dan Nuraini dalam posisinya sebagai perempuan tidak menjadi dominan dan substantif karena yang muncul adalah posisi mereka sebagai orang yang lebih berpendidikan, berkecukupan, berpengaruh, dan berusia dewasa. Kategorikategori tersebut menjadi hal yang utama sebagai penentu apakah mereka berhak untuk berkontribusi atau "memberi" ketimbang posisinya sebagai perempuan.

Kompleksitas dan interkoneksitas isu gender dengan isu-isu lainnya karena gender adalah hanya salah satu bagian dari kategori sosial atau identitas yang inheren dengan kehidupan individu. Manusia sebagai makhluk yang memiliki multiple identity memang diwarnai oleh dialektika antaridentitas-identitas dan ketegori-kategori sosial ini. Perempuan pun tidak bisa dipandang hanya sebagai perempuan yang notabene merupakan salah satu varian dari identitas mereka, tetapi juga perlu dilihat secara bijaksana berdasarkan identitas-identitas lainnya. Melihat perempuan atas dasar jenis kelamin dan secara simultan dengan kategori sosial lainnya misalnya ekonomi memberikan gambaran yang utuh bagaimana memperlakukan relasi perempuan dan lakilaki secara lebih komprehensif. ${ }^{21}$

Sebaliknya, diskriminasi tidak hanya terjadi atas dasar jenis kelamin dan gender, tetapi juga atas dasar keragaman lainnya misalnya, kemiskinan, kecacatan, bahasa, etnis, budaya, gaya hidup, dan masih banyak lagi. Oleh karena itu, menghargai adanya keragaman identitas dan bervariasinya kategori sosial berarti pula menyadari bahwa diskriminasi bisa bersumber dari berbagai aspek. Konsekuensinya, perjuangan antidiskriminasi melalui perspektif gender terjalin-kelindan dengan perspektif-

${ }^{21}$ Lebih jauh tentang bagaimana kecenderungan sosial menyederhanakan posisi perempuan hanya sebagai istri, lihat tulisan Atun Wardatun "Menggugat Istrinisasi Perempuan" Qawwam Journal for Gender Mainstreaming, no. 1 (Juni 2007), 64-71. 
perspektif antidiskriminasi lainnya. Hal inilah yang menjadi substansi konsep interseksionalitas gender yang digaungkan oleh multicultural feminism tersebut.

Pendeknya, perjuangan menyetarakan manusia atas dasar jenis kelamin dan gender tentu juga harus bermakna menolak diskriminasi atas nama apa pun dengan menciptakan solidaritas lintas gerakan atas kesamaan kepentingan dan tujuan.

\section{Catatan Akhir}

Ampa co'i ndai sebagai sebuah kearifan lokal tentu bisa dipandang dari berbagai perspektif. Bisa jadi tradisi ini dipandang sebagai penentangan terhadap kebiasaan umum masyarakat (anomali) atau cara masyarakat mendistorsi kesepakatan yang sudah baku. Pandangan semacam itu sah-sah saja. Keragaman persepsi melihat fakta adalah wajar bergantung pada point of view yang mendasari persepsi tersebut. Hanya saja tulisan ini bukan upaya judgmental yang melihat sebuah fakta secara hitam putih, tetapi hanya interpretasi dari sebuah fakta sesuai dengan yang penulis pahami berdasarkan analisis gender.

Perspektif gender melihat bahwa tradisi ampa co'i ndai adalah upaya kompromi terhadap idealitas ekspektasi budaya dan doktrin agama yang membebankan tanggung jawab yang bernilai ekonomis "hanya" pada laki-laki dan realitas masyarakat yang dalam banyak hal berbanding terbalik. Karena idealitas laki-laki sebagai pihak yang lebih tinggi ternyata tidak selalu ditemukan dalam fakta sehari-hari, untuk mempertahankannya, pengkategorian laki-laki dan perempuan kadang-kadang tidak lagi berdasarkan jenis kelamin, tetapi berdasarkan kategori sosial lainnya, misalnya tingkat ekonomi dan pendidikan. Dalam kasus ampa co'i ndai, perempuan berkontribusi dalam pengadaan mahar bukan karena dia perempuan, tetapi karena ia memiliki kategori sosial yang lebih tinggi daripada laki-laki. Konsekuensinya, dalam ikrar ijab qabul, mahar tetap diatasnamakan laki-laki. Kasus ini membuktikan bahwa membincang isu gender tidak bisa dilepaskan dari isu-isu berdasarkan ragam kategori sosial lainnya. Inilah yang disebut dengan gender intersectionality. Interseksionalitas gender inilah yang hendaknya menjadi dasar 
bagi wacana dan studi gender selanjutnya sehingga penyikapan terhadap problema gender menjadi lebih komprehensif.

Interpretasi yang dipaparkan di atas masih berupa preeliminary penafsiran yang memerlukan eksplorasi yang lebih mendalam. Masih banyak aspek ampa co'i ndai ini yang perlu lebih serius didalami. Misalnya, bagaimana relasi yang terjadi pada rumah tangga yang melakukan ampa co'i ndai. Adakah pengaruhnya terhadap posisi tawar dan relasi antara suami istri, mengingat rumah tangga tersebut dibangun atas dasar kompromi dan negosiasi terhadap posisi hierarkhis antara lakilaki dan perempuan, yang merupakan nilai dari ampa co'i ndai ini? Keterbatasan tulisan ini bisa menjadi dasar bagi studi selanjutnya. Wa al-Lâh a lam bi al-shawâb.

\section{Daftar Pustaka}

Atun Wardatun, Negosiasi Ruang: Antara Runag Publik dan Domestik (Mataram: PSW IAIN Mataram Press, 2007). "Menggugat Istrinisasi Perempuan" dalam Qawnam Journal for Gender Mainstreaming, Vol. 2, No. 1, 2007. Ahmad ibn Hanbal, al Musnad, Juz VI.

Chandra Talpade Mohanty, Feminism without Borders: Decolonizing Theory Practicing Solidarity (Durham\&London: Duke University Press, 2003).

Fachrir Rahman, Islam di Bima: Kajian Historis tentang Proses Islamisasi dan Perkembangannya Sampai Masa Kesultanan (Yogyakarta: Genta Press, 2009).

Husein Muhammad, Fiqh Perempuan: Refleksi Kyai atas Wacana Agama dan Gender (Yogyakarta: LKiS, 2001).

Iman Sudiyat, Hukum Adat: Sketsa Asas, (Yogyakarta: Liberty, 1987).

Judith Lorber, Gender Inequality: Feminist Theories and Politics (California: Roxbury Publishing Company, 2001)

Kompilasi Hukum Islam (KHI) No. 1/1991.

Muslihun, "Relasi Suami dan Istri berdasarkan Nash (Studi Kasus Masyarakat Muslim Sasak)" dalam Menolak Subordinasi Menyeimbangkan Relasi: Beberapa Catatan Reflektif Seputar Islam dan Gender (Mataram: PSW IAIN Mataram Press, 2007). 
Nurhilaliati, "Perempuan dan Mahar" dalam Menolak Subordinasi, Menyeimbangkankan Relasi: Beberapa Catatan Reflektif Seputar Islam dan Gender" (Mataram: PSW IAIN Mataram Press, 2007).

Sayid Sabiq, Fiqh al Nisâ' (Beirut: Dar al Fikr, 1992).

Zaitunah Subhan, Menggagas Fiqh Pemberdayaan Perempuan (Jakarta: El Kahfi, 2008). 